\section{スカンジゥムのアセチルアセトン錯体 のガスクロマトグラフィー}

藤永太一郎, 桑本 融, 小野 祐資*

$$
1 \text { 緒言 }
$$

無機化合物ガスクロマトグラフィーに関する研究法従 来，永久気体1)，水素化合物2 および八ロゲン化物引を 対象とする研究がほとえどであった。しかし，最近にい たって低沸点の有機金属化合物，たとえば，鉛4)，ゲル マニウム5)などのテトラメチル化合物，ベリリウム，ア ルミニウムのアセチルアセトネート6)r), アルミニウム， クロム, ロジウムのフッ化アセチルアセトネート8)など の研究がみられるようになってきている・著者らは，土 類金属のアセチルアセトネートがこのように低沸点にあ る点に注目し，特にスカンジウムについてそのガスクロ マ.トグラフ的挙動を検討した。

\section{2 試料および装置}

アセチルアセトンスカンジウム $\left[\mathrm{Sc}\left(\mathrm{CH}_{3} \cdot \mathrm{CO} \cdot \mathrm{CH}\right.\right.$. $\left.\mathrm{COCH}_{3}\right)_{3}$ ]の調製9)10) : スカンジウムの酸化物 $\left(\mathrm{Sc}_{2} \mathrm{O}_{3}\right)$ を $500 \mathrm{mg}$ とり，完全に溶解するまで硝酸を加え加熱す る. 溶解後 $10 \mathrm{~m} l$ の蒸留水を加えて 希釈し, 口過して 不純物をとり除く. 次に $1 N$ アンモニア水を加えて中 和し, 得られた水酸化スカンジウムの沈殿に計算量のア セチルアセトンを加えて 30 分放置したのち, 分液ロー トに移し $100 \mathrm{ml}$ のクロロホルムを加えて十分に振り混 ぜ,クロロホルム層をとり出す．減压によってクロロホ ルムをとり除くと，アセチルアセトンスカンジウム 下, $\mathrm{Sc}(\mathrm{AA})_{3}$ と略記する\} の結晶が得られる. クロロ ホルムで再結晶を繰返し試料とする．融点測定の結果， $180^{\circ} \mathrm{C}$ 洨交献記載值と ${ }^{11)}$ とよく一致する. この結晶 $\mathrm{Sc}(\mathrm{AA})_{3}$ をえクロてんびんでひょう取し，固形サンプ ル導入用試料筒に入れ，気化室にとう入する. 装置法， 熱伝導度型検出器をつ島津製作所製 $\mathrm{GC}-1 \mathrm{~B}$ 型を使用 した. カラム充てん剂は, 柴田化学機器工業 $\mathrm{K} \mathrm{K}$ 製のグ ラスビーズ(60〜80メッシュ)100 g に 500mg の Apiezon L をコーティングしたものを $60 \mathrm{~g}$ とり， $150 \mathrm{~cm}$

\footnotetext{
* 京都大学理学部化学教室
}

の分離管に充てえして使用した。

\section{3 気化温度の検討}

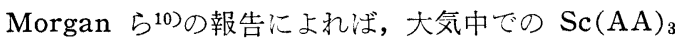
の融点は $180^{\circ} \mathrm{C}$ であり，昇華点注 $210^{\circ} \mathrm{C}$ であるとされ ている．従って，分離管の温度を，昇華点より高く 250 ${ }^{\circ} \mathrm{C}$ に保ち, 気化室の温度を $180^{\circ} \mathrm{C}$ から $250^{\circ} \mathrm{C}$ まで変 化させて, $\mathrm{Sc}(\mathrm{AA})_{3}$ の気化の状態を検討した．その結 果 Fig. 1 亿図示したように, $200^{\circ} \mathrm{C}$ 前後から気化する ものと推定される.さてなるべく気化温度を高くして， 気化速度をすみやかにするために, 気化室温度を $310^{\circ} \mathrm{C}$ に上昇せしめ実験を行なった結果，試料の分解は認めら れず，気化温度の低い場合より良好なガスクロマトグラ ムを得た。安た，ヘリウム気流中では分離管を通った試 料法分離管の出口に打いて再び凝縮することを認めた。 従って, 本分離法によって $\mathrm{Sc}(\mathrm{AA})_{3}$ 沙分解しないと考 えられる。

Temperature of flash room, ${ }^{\circ} \mathrm{C}$

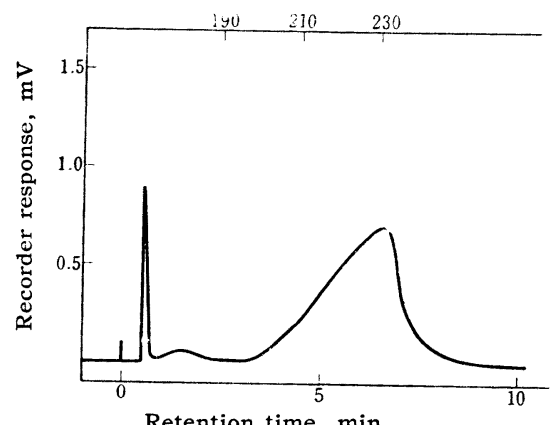

Fig. 1 Chromatogram of scandium acetylacetonate

Column : $1.5 \mathrm{~m}, 0.5 \%$ Apiezon-L on $60 \sim 80$ mesh glass beads Temp.: $250^{\circ} \mathrm{C}$

Helium flow : $80 \mathrm{ml} / \mathrm{min}$ Filament current : $130 \mathrm{~mA}$

\section{4 分離管の温度の検討}

以上の検討の結果にもとづき $310^{\circ} \mathrm{C}$ において試料気 化を行なうとともに，分離管の温度を $200^{\circ} \mathrm{C}$ から 250 ${ }^{\circ} \mathrm{C}$ まで $10^{\circ} \mathrm{C}$ ごとに上昇せしめて，それぞれのガスク ロマトグラムを記録した。その結果, $200^{\circ} \mathrm{C} て ゙ は$ 試料の ピークは明らかにテーリングが激しく定量可能なピーク は得られず, $210^{\circ} \mathrm{C}$ から $220^{\circ} \mathrm{C}$ までは, 定量可能な明 確なピークが得られる。また， $230^{\circ} \mathrm{C}$ 以上になると， Rt が短く望ましくないことが明らかになった。 


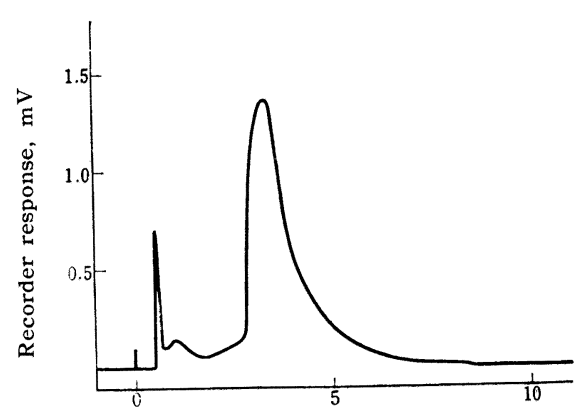

Retention time, min

Fig. 2 Chromatogram of scandium acetylacetonate

Column : $1.5 \mathrm{~m}, 0.5 \%$ Apiezon-L on glass beads Temp. : $220^{\circ} \mathrm{C}$

Helium flow $80 \mathrm{ml} / \mathrm{min}$ Filament current $: 130 \mathrm{~mA}$ Flash temp. : $310^{\circ} \mathrm{C}$

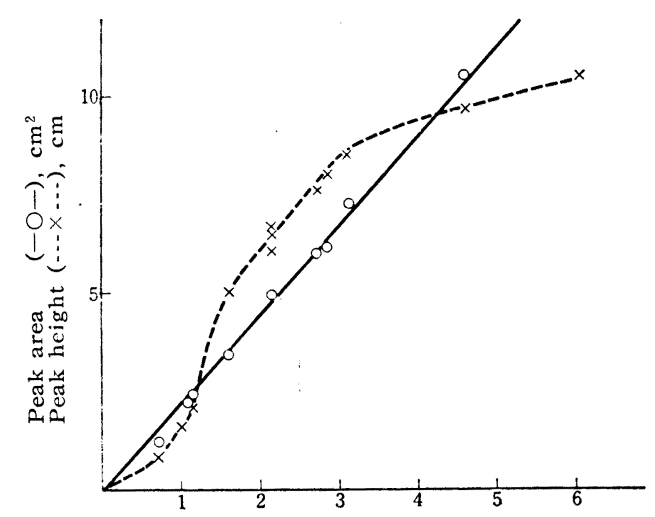

Amounts of Sc-acetylacetonate (Solid), mg

Fig. 3 Calibration curve

5 検量線の作成

以上の検討により, 分離管の温度を $220^{\circ} \mathrm{C}$, 気化室 の温度老 $310^{\circ} \mathrm{C}$ に調整して，1〜 $5 \mathrm{mg}$ の試料をひょう 取し，供試してガスクロマトグラムを記録すると，Fig. 2 に示されるようなガスクロマトグラムが得られた. 面 積老測定し, 検量線を求めると, Fig. 3 に示すように 比例性があり, 誤差 $\pm 2 \%$ 以内で測定可能であった。し
かしピークの高さでは比例性は認められない.

$$
6 \text { 結 論 }
$$

スカンジウムの定量のために，アセチルアセトンスカ ンジウムを試料として，ガスクロマトグラフを用いる分 析法を検討した. その結果, Apiezon-L グラスビーズ を充てん剂として，満足すべき定量が可能であることを 見いだした. 固体を試料としたため, 特に気化室と分離 管の温度に注目検討し, 前者の温度 $310^{\circ} \mathrm{C}$, 後者の温 度 $220^{\circ} \mathrm{C}$ に調整すればよいことがわかった。また，1〜 $5 \mathrm{mg}$ の錯体では $\pm 2 \%$ 以内の䛊差で比例性があること を認めた. なお, 分配液相, 担体の検討および微量スカ ンジウムの定量のためのアセチルアセトン抽出法などに ついては别に報告する。

\section{交献}

1) F. R. Bryan, J. C. Neerman : Anal. Chem., 34, 278 (1962).

2) 藤永太一郎, 篠原 遥: 化学の領域増刊, 第53号 (ガスクロマトグラフィ一第 4 集), (1962); クロ マトグラフ討論会（1961年 1 月).

3) J. F. Ellis, G. Iveson (ed. D. H. Desty) : "Gas Chromatography", p. 300 (1958), (Butterworths Scientific Publications, London).

4) E. W. Abel, G. Nickless, F. H. Pollad : Proc. Chem. Soc., 288 (1960).

5) J. I. Peterson: C \& EN., May 1 (1961).

6) W. J. Birman, Hyman Gesser : Anal. Chem., 32, 1525 (1960).

7) A. A. Duswalt, Jr.: “ Analytical Application of Gas Chromatography", (1959), (Thesis, Purdue University, Lafayett, Ind.); J. Chromatography, 5, 225 (1961).

8) R. E. Sievers, B. W. Ponder, M. L. Morris, R. W. Moshier : Inorg. Chem., 2, 693 (1963). Chem. Eng. News, 41, 41 (1963).

9) R. J. Meyer, H. Winter: Z. anorg. Chem., 95, 438 (1919).

10) F. M. Jaeger : Rec. trav. chem. Pays-Bas, 33, 385 (1914).

11) G. T. Morgan, H. W. Moss : J. Chem. Soc., 105, 189 (1914).

(昭和 38 年 10 月 3 日受理) 